\title{
Właściwości mechaniczne złączy ze staliwa stopowego GX5CrNi13-4 a technika spawania
}

\author{
Mechanical properties of joints in the steel alloy GX5CrNi13-4 \\ and welding technology
}

\section{Streszczenie}

Badaniu poddano złącza spawane staliwa GX5CrNi13-4. Złącza zespawano wykorzystując różne techniki spawania metodą MMA (111) w pozycjach: PC i PF. $\mathrm{Na}$ uzyskanych złączach wykonano nieniszczące i niszczące badania ich jakości. Przeprowadzone badania wytrzymałości na rozciąganie oraz próby gięcia złączy spawanych wykazały, że niezależnie od pozycji i techniki spawania, otrzymane połączenia spełniają wymagania normy dla materiału rodzimego. Udarność złącza spawanego w pozycji PF niezależnie od temperatury badania spełniała zarówno wymagania przepisów DNV, jak i normy materiałowej. W przypadku pozycji PC badane złącze w spoinie spełniało wymagania minimalnej udarności w temperaturze obniżonej, natomiast $\mathrm{w}$ temperaturze otoczenia - nie. Twardość złącza spawanego po obróbce cieplnej niezależnie od pozycji spawania była niższa od wartości 350 HV. Rozkład twardości w złączu spawanym w pozycji PF charakteryzował się mniejszym gradientem twardości na przekroju w porównaniu do złącza spawanego w pozycji PC. Wykazano, że można uzyskać złącze o bardzo dobrych właściwościach wytrzymałościowych staliwa o ograniczonej spawalności, jeżeli zastosuje się właściwą technologię spawania.

Słowa kluczowe: staliwo GX5CrNi13-4, energia liniowa, właściwości mechaniczne

\section{Abstract}

The investigation was carrier out on welded joints of GX5CrNi13-4 cast steel. The joints were welded using various welding techniques with the MMA method (111) in the positions: PC and PF. On the obtained joints, the non-destructive and destructive tests of their quality were performed. These tests have shown a correct structure of the joints, without any welding non-conformities. The tests of tension and bending carried out on the welded joints have shown that the obtained results fulfil the standard requirements for the base material, regardless of the position and technique of welding. Impact strength of the welded joint in position PF met both the requirements of DNV regulations, as well as material standard, irrespective of the temperature of testing. In the case of position $\mathrm{PC}$, the welded joint in the weld seam fulfilled the requirements of minimum impact strength at decreased temperature, whereas at room temperature - it did not. The distribution of hardness of the welded joint in the cross section after heat treatment, regardless of the welding position, was lower than the value of $350 \mathrm{HV}$. Hardness distribution in the welded joint in position PF was characterized by a smaller gradient of hardness in the cross section, compared with the welded joint in position PC. It has been proved that obtaining a joint of very good strength properties for the cast steel of limited weldability is possible if a proper welding technology is applied.

Keywords: GX5CrNi13-4 cast steel, heat input, mechanical properties

\section{Wstęp}

Nowoczesny przemysł metalowy wymaga stosowania specjalnych materiałów, których spawalność metalurgiczna, technologiczna i konstrukcyjna jest ograniczona. Obraz licznych zmagań inżynierów spawalników z nowowprowadzanymi stalami i staliwami ukazany jest np. w pracach $[1 \div 6]$. Do grupy materiałów o podwyższonym ryzyku spawania należą również stale i staliwa chromowo-niklowe z miękkim martenzytem, których obostrzone reżimy spawania, podane np. w pracy [7] z pewnością nie są kompletne, szczególnie dla trudnoodkształcalnych złączy staliwnych o znacznej grubości. Niniejsza praca stanowi przyczynek do uzupełnienia tego braku wiedzy - o potencjalnie korzystne i niekorzystne techniki spawania. Stale i staliwa chromowe i chromowo-niklowe o niewielkiej zawartości niklu stanowią grupę materiałów o ograniczonej spawalności [7]. Dlatego też technologie ich spawania muszą być dokładnie zaplanowane i przestrzegane podczas wykonywania. Złącza spawane właściwą metodą, prawidłowo dobranym materiałem dodatkowym i obróbką cieplną mogą jednak okazać się niespełniającymi wymagań, co wykazuje niniejsza praca.

Dr inż. Kwiryn Wojsyk, mgr inż. Joanna Jasak; dr hab. inż. Grzegorz Golański, mgr inż. Jerzy Kupczyk - Politechnika Częstochowska. 


\section{Materiał i metodyka badań}

Materiałem przeznaczonym do badań były złącza spawane staliwa GX5CrNi13-4 o grubości $30 \mathrm{~mm}$. Złącza zespawano wykorzystując różne techniki spawania (ściegi), metodą MMA (111) w pozycjach: PC (naściennej) i PF (pionowej). Zastosowano materiał dodatkowy w postaci elektrod FOX CN 13/4: EN 1600 E 134 b 6 2. Skład chemiczny materiału podstawowego i dodatkowego przedstawiono w tablicy I. W tablicy II zestawiono natomiast wymagania dotyczące właściwości mechanicznych badanego staliwa. Przed spawaniem materiały podstawowe podgrzano do temperatury ok. $150{ }^{\circ} \mathrm{C}$. W trakcie spawania temperatura międzyściegowa nie przekraczała $200{ }^{\circ} \mathrm{C}$. Uzyskane złącza poddano obróbce cieplnej, polegającej na ich stopniowym nagrzewaniu z szybkością $60^{\circ} \mathrm{C} / \mathrm{h}$ do temperatury $580-600^{\circ} \mathrm{C} / \mathrm{h}$ i wygrzewaniu w tej temperaturze przez 4 godziny. Następnie złącza były studzone w piecu do temperatury $250{ }^{\circ} \mathrm{C}$, a dalsze chłodzenie odbywało się w powietrzu [8].

W celu oceny prawidłowości wykonanych złączy spawanych zostały one poddane badaniom: nieniszczącym - penetracyjnym (PT) i radiograficznym (RT) w zakresie $100 \%$ z uwzględnieniem poziomu jakości B wg PN-EN ISO 5817 , metalograficznym oraz badaniom właściwości mechanicznych. Badania mikrostrukturalne złączy spawanych wykonano za pomocą mikroskopu świetlnego Axiovert 25. Obserwację i rejestrację mikrostruktur przeprowadzono na przygotowanych zgładach metalograficznych, trawionych odczynnikiem metalograficznym $-\mathrm{FeCl}_{3}$. Zakres przeprowadzonych badań mechanicznych obejmował: pomiar twardości metodą Vickersa przy obciążeniu 98 N (10 kG), próbę udarności, statyczną próbę rozciągania oraz boczną próbę zginania na próbkach płaskich. Do gięcia zastosowano trzpień o średnicy $18,9 \mathrm{~mm}$ przez co kryterium oceny zostało zaostrzone. Kryterium pozytywnym tej próby było uzyskanie kąta gięcia $180^{\circ}$ bez wystąpienia rys i pęknięć na rozciąganej powierzchni próbki. Próbę udarności przeprowadzono w temperaturze pokojowej i temperaturze obniżonej $\left(-10^{\circ} \mathrm{C}\right)$ stosując standardowe próbki typu Charpy V. Uzyskany wynik jest średnią trzech prób. Badania właściwości mechanicznych przeprowadzono wg obowiązujących norm.

\section{Badania nieniszczące i metalograficzne}

Badania nieniszczące złącza - penetracyjne i ultradźwiękowe - wykazały, że badane złącza charakteryzują się poziomem jakości B wg wymagań PN-EN ISO 5817. Badania makroskopowe na przekrojach złączy nie ujawniły obecności pęknięć i nieciągłości oraz potwierdziły właściwy kształt spoiny, prawidłową budowę poszczególnych stref złącza spawanego oraz układ ściegów bez innych znaczących niezgodności spawalniczych (rys. 1 i 2).

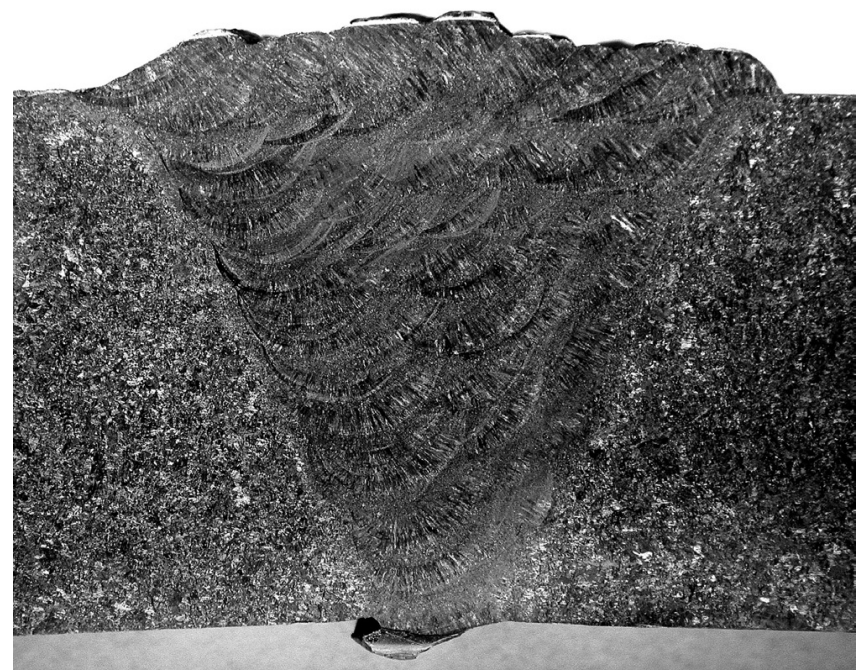

Rys. 1. Makroskopowy obraz badanego złącza spawanego, pozycja spawania - PC, grubość złącza - $30 \mathrm{~mm}$

Fig. 1. Macroscopic image of the examined welded joint, welding position - PC, joint thickness - $30 \mathrm{~mm}$

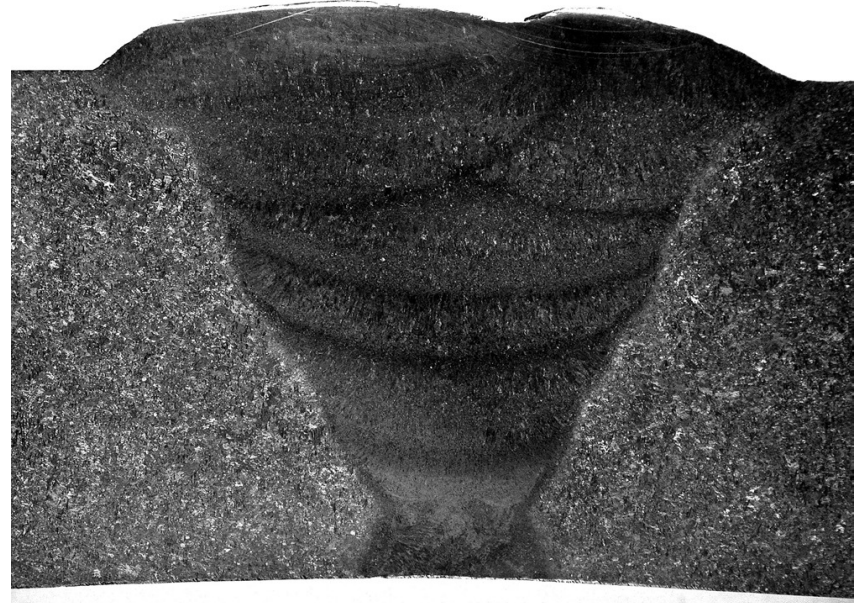

Rys. 2. Makroskopowy obraz badanego złącza spawanego, pozycja spawania - PF, grubość złącza - $30 \mathrm{~mm}$

Fig. 2. Macroscopic image of the examined welded joint, welding position - PF, joint thickness $-30 \mathrm{~mm}$

Złącza różnią się jednak istotnie ilością ułożonych ściegów, a zatem i obszarów podlegających samoczynnej obróbce cieplnej wokół nich. Wydawać by się mogło, że struktury powstające z złączu pokazanym na rysunku 1 są korzystniejsze dla właściwości mechanicznych złącza od struktur obecnych w złączu przedstawionym na rysunku 2. Złącza te różnią się jednak sumaryczną energią liniową spawania.

Tablica I. Skład chemiczny materiału podstawowego i dodatkowego, \% wag

Table I. Chemical composition of basic and additional material, \% wt

\begin{tabular}{|c|c|c|c|c|c|c|c|c|}
\hline Materiał & C & Si & Mn & P & S & Cr & Mo & Ni \\
\hline GX5CrNi13-4 & 0,04 & 0,56 & 0,46 & 0,012 & 0,008 & 13,38 & 0,46 & 4,44 \\
\hline FOX CN 13/14 & 0,04 & 0,30 & 0,43 & 0,011 & 0,006 & 11,92 & 0,50 & 4,38 \\
\hline
\end{tabular}

Tablica II. Wymagane właściwości mechaniczne staliwa GX5CrNi13-4

Table II. Required mechanical properties of GX5CrNi13-4 cast steel

\begin{tabular}{|c|c|c|c|c|c|c|}
\hline Oznaczenie & Numer & $\begin{array}{c}\mathrm{R}_{\mathrm{p} 0,2} \\
\mathrm{MPa}\end{array}$ & $\begin{array}{c}\mathrm{R}_{\mathrm{m}} \\
\mathrm{MPa}\end{array}$ & $\begin{array}{c}\mathrm{A} \\
\%\end{array}$ & $\begin{array}{c}\mathrm{KV} \\
\mathrm{J}\end{array}$ & $\mathrm{HB}$ \\
\hline GX5CrNi13-14 & 1.4313 & $\min 500$ & $760 \div 960$ & $\min .15$ & $\begin{array}{c}\min 30 \\
\left(-10^{\circ} \mathrm{C}\right)\end{array}$ & $240 \div 300$ \\
\hline
\end{tabular}


Badania mikrostrukturalne nie wykazały obecności obszarów o niekorzystnej strukturze. Mikrostruktura złącza w każdej jego strefie składała się z martenzytu odpuszczonego (rys. 3 i 4) o różnych morfologiach.

\section{Badania właściwości mechanicznych}

Przeprowadzone badania wytrzymałości na rozciąganie złączy spawanych wykazały, że niezależnie od pozycji i techniki spawania, a więc ilości użytych ściegów i wprowadzonej energii wytrzymałość złączy była wyższa od wartości
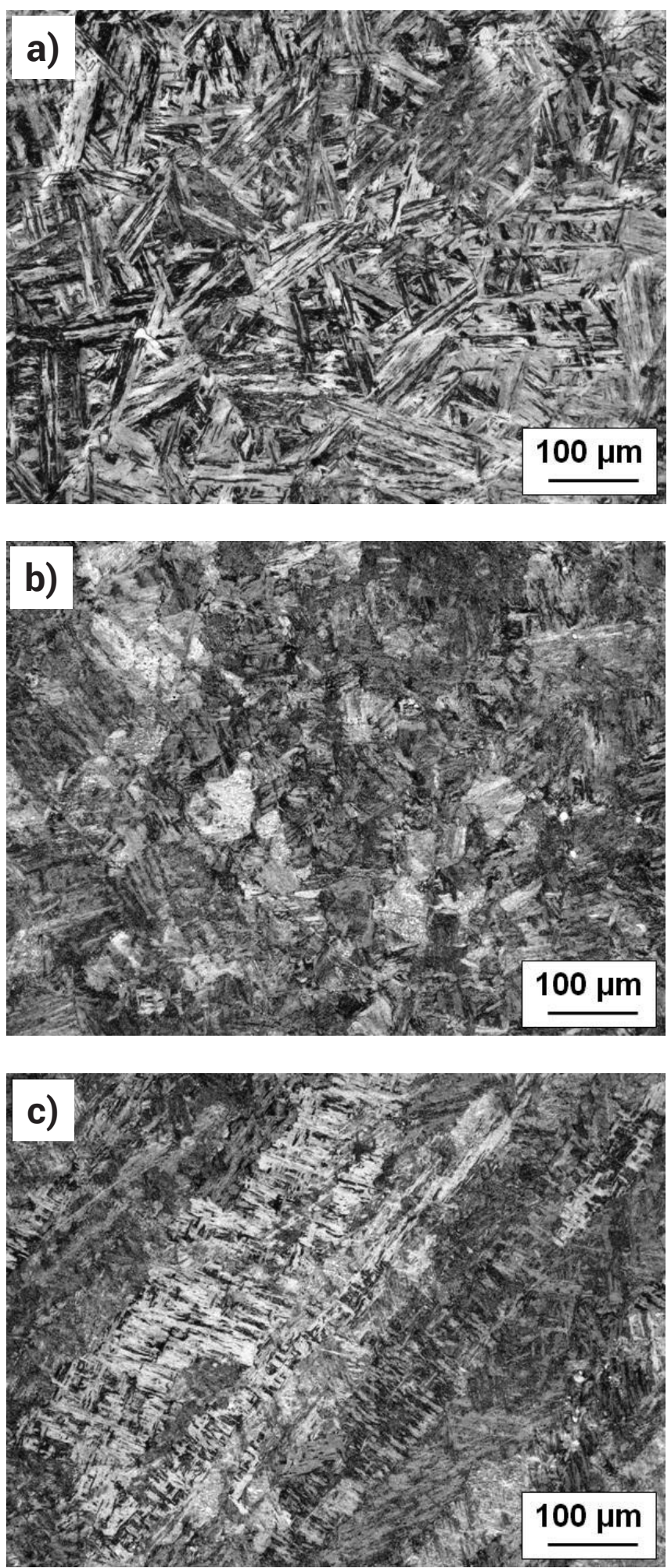

Rys. 3. Mikrostruktura złącza spawanego, pozycja spawania PC: a) materiał rodzimy, b) strefa wpływu ciepła, c) spoina, OM

Fig. 3. The microstructure of welded joint, welding position PC: a) parent material, b) heat affected zone, c) joint, OM
$840 \mathrm{MPa}$ (tabl. III), a uzyskane wyniki spełniają wymagania normy dla materiału rodzimego (tabl. II). Zerwanie próbek w czasie rozciągania następowało w materiale rodzimym.

Tablica III. Wytrzymałość na rozciąganie złączy

Table III. The tensile strength of welding joints

\begin{tabular}{|c|c|c|}
\hline $\begin{array}{c}\text { Pozycja } \\
\text { spawania }\end{array}$ & $\begin{array}{c}\mathrm{R}_{\mathrm{m}}, \\
\mathrm{MPa}\end{array}$ & $\begin{array}{c}\text { Miejsce } \\
\text { zerwania }\end{array}$ \\
\hline PC & 841,884 & $\begin{array}{c}\text { Materiał } \\
\text { podstawowy }\end{array}$ \\
\hline PF & 852,860 & P \\
\hline
\end{tabular}
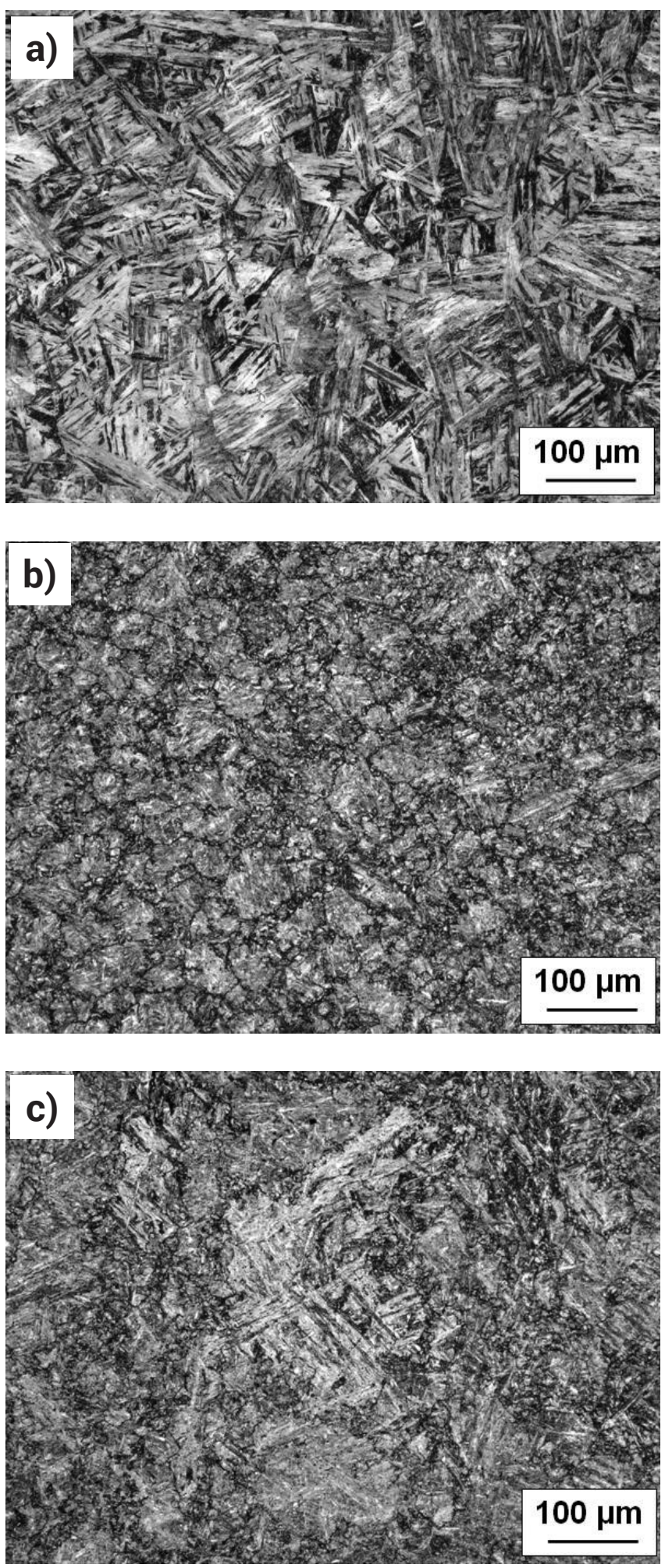

Rys. 4. Mikrostruktura złącza spawanego, pozycja spawania PF: a) materiał rodzimy, b) strefa wpływu ciepła, c) spoina, OM

Fig. 4. The microstructure of welded joints, welding position PF: a) parent material, b) heat affected zone, c) joint, OM 
Wykazano, że złącza po obróbce cieplnej niezależnie od sposobu spawania, spełniały wymóg właściwego kąta gięcia tj. kąt $180^{\circ}$ bez wystąpienia rys i pęknięć na rozciąganej powierzchni próbki (rys. 5 i 6).

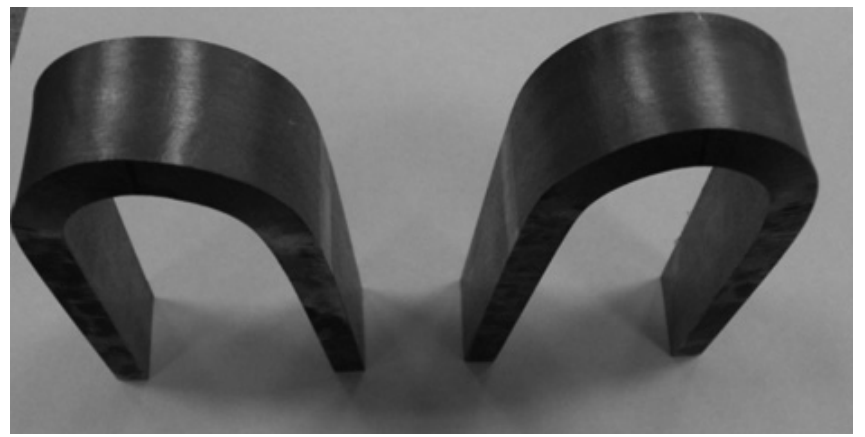

Rys. 5. Zgięte próbki, pozycja spawania - PC, kąt zginania $180^{\circ}$

Fig. 5. Bent test samples, welding position - PC, bending angle $180^{\circ}$

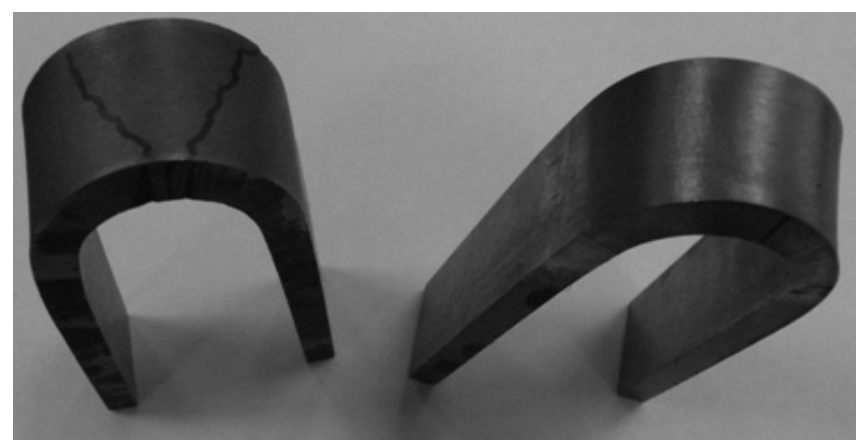

Rys. 6. Zgięte próbki, pozycja spawania - PF, kąt zginania $180^{\circ}$ Fig. 6. Bent test samples, welding position - PF, bending angle $180^{\circ}$

Udarność złącza spawanego w pozycji PF (rys. 7 i 8) zarówno w temperaturze obniżonej, jak i w temperaturze pokojowej spełniały zarówno wymagania przepisów DNV oraz normy materiałowej. W przypadku pozycji PC (rys. 9 i 10) badane złącze w spoinie spełniało wymagania minimalnej udarności $w$ temperaturze obniżonej, natomiast $w$ temperaturze otoczenia - nie. W przypadku pozycji PF energia liniowa spawania pojedynczego ściegu złącza wynosiła 2-3 kJ/mm, natomiast w pozycji PC była niższa i mieściła się w zakresie 0,4 - $1 \mathrm{~kJ} / \mathrm{mm}$. Sumaryczna ilość ciepła wprowadzonego była jednak różna dla obu złączy, co może być przyczyną niższej udarności spoiny wykonanej w pozycji PC. Widoczne jest również (rys. $7 \div 10$ ), że wartości udarności badanego materiału dla danej pozycji, niezależnie od temperatury łamania były zbliżone do siebie. Wpływ na powyższe może mieć dodatek niklu, który przyczynia się do zmniejszenia wrażliwości staliwa na kruchość związaną z obniżaniem temperatury.

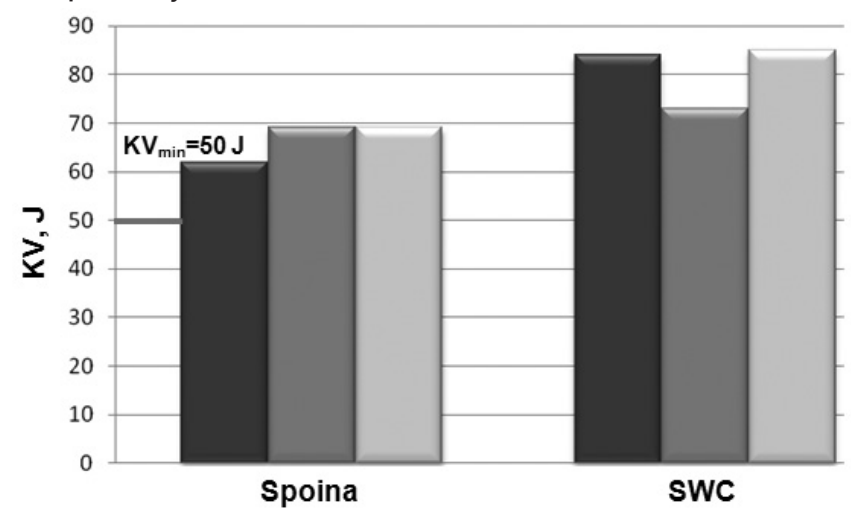

Rys. 7. Udarność złącza spawanego w temperaturze pokojowej w zależności od miejsca pobrania próbek, pozycja PF

Fig. 7. The impact strength of the welded joint at room temperature, depending on the place of taking sample, the position PF

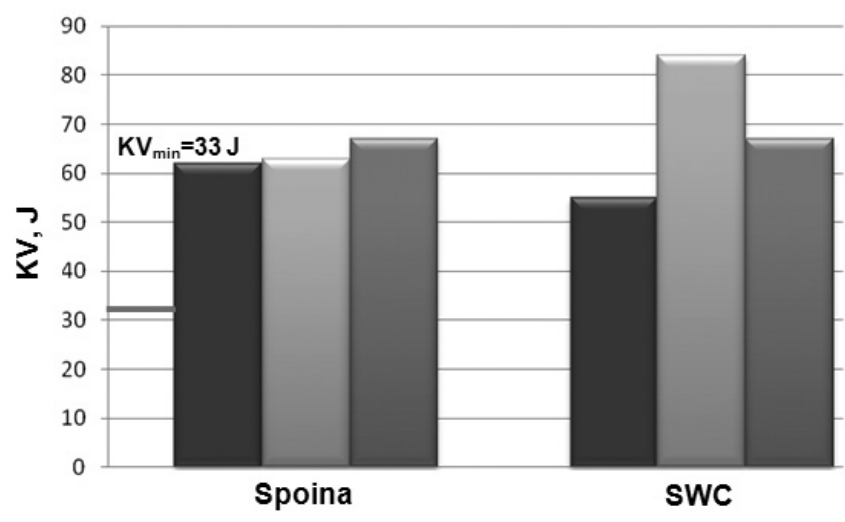

Rys. 8. Udarność złącza spawanego $w$ temperaturze $-10{ }^{\circ} \mathrm{C} w$ zależności od miejsca pobrania próbek, pozycja PF

Fig. 8. The impact strength of the welded joint at a temperature of $-10^{\circ} \mathrm{C}$, depending on the place of taking sample, the position PF

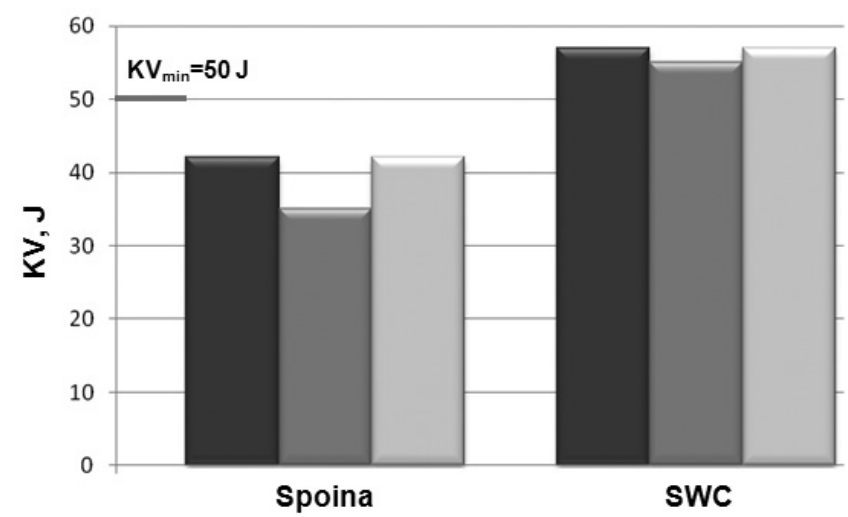

Rys. 9. Udarność złącza spawanego w temperaturze pokojowej w zależności od miejsca pobrania próbek, pozycja PC

Fig. 9. The impact strength of the welded joint at room temperature, depending on the place of taking sample, the position PC

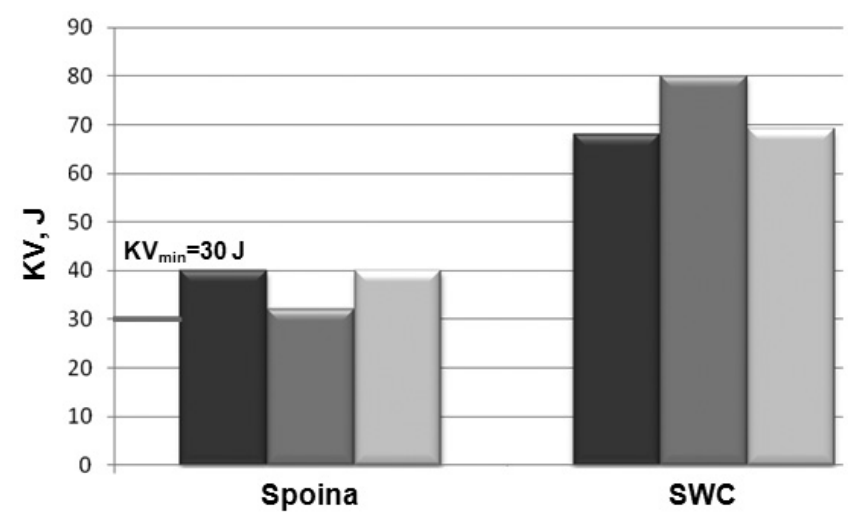

Rys. 10. Udarność złącza spawanego w temperaturze $-10{ }^{\circ} \mathrm{C}$ w zależności od miejsca pobrania próbek, pozycja PC

Fig. 10. The impact strength of the welded joint at a temperature of $-10^{\circ} \mathrm{C}$, depending on the place of taking sample, the position PC

Rozkład twardości HV10 dla danej pozycji spawania na przekroju badanego złącza przedstawiono na rysunkach 11 i 12.

Twardości złącza spawanego na przekroju - niezależnie od pozycji spawania - po obróbce cieplnej były niższe od wartości $350 \mathrm{HV}$. Twardość $350 \mathrm{HV}$ jest umownym poziomem granicznym. Przyjmuje się, że powyżej tej wartości złącze traci obrabialność oraz wykazuje skłonność do pęknięć zimnych. Widoczne jest (rys. 11 i 12), że rozkład twardości w złączu spawanym w pozycji PF (rys. 12) charakteryzuje się mniejszym gradientem twardości na przekroju złącza w porównaniu do złącza spawanego w pozycji PC (rys. 11). Świadczy to o przeprowadzonych skuteczniej zabiegach cieplnych zarówno w czasie, jak i po spawaniu na złączu wykonanym w pozycji PF. Ponieważ po spawaniu oba złącza poddane zo- 


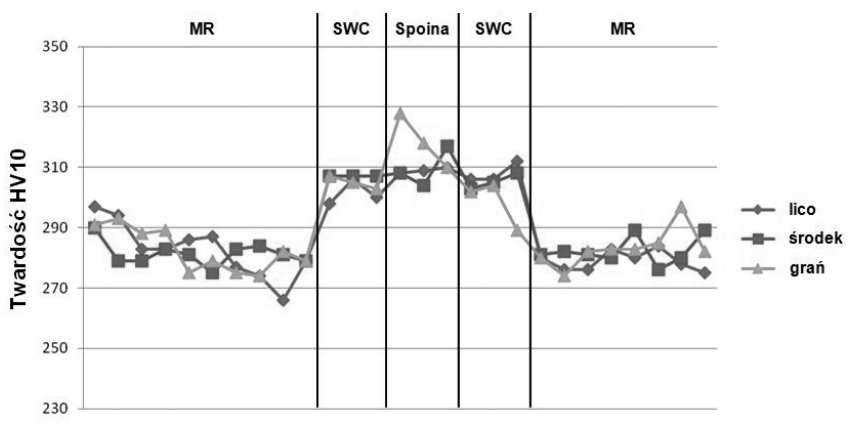

Rys. 11. Rozkład twardości złącza spawanego, pozycja PC Fig. 11. Distribution of hardness of welded joint, position PC

stały identycznym obróbkom cieplnym, wyłączną przyczyną pozostałych różnic mogła być technika spawania, która okazała się korzystniejsza dla złącza wykonywanego w pozycji PF - ściegami zakosowymi. Rezultat ten staje się jasny na tle wieloletnich doświadczeń przedstawionych np. w pracy [9] wykazujących, że zwiększona liczba układanych w rowku

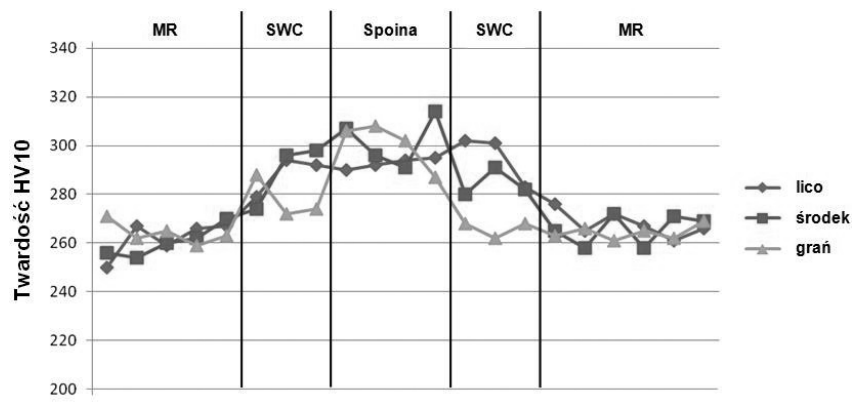

Rys. 12. Rozkład twardości złącza spawanego, pozycja PF Fig. 12. Distribution of hardness of welded joint, position PF

spawalniczym ściegów owocuje większymi odkształceniami złącza, a gdy jest to niemożliwe (gdy złącze jest sztywne - jak w przypadku staliw o znacznej grubości) naprężeniami pospawalniczymi. Najprawdopodobniej jest to również przyczyną podwyższonej kruchości (obniżonej udarności) złącza wykonanego w pozycji PF.

\section{Podsumowanie}

Badaniu poddano złącza spawane wykonane na płytach o grubości $30 \mathrm{~mm}$ ze staliwa GX5CrNi13-4. Badane złącza uzyskano spawając je metodą MMA (111) w przymusowych pozycjach: PC (naściennej) i PF (pionowej) stosując odpowiednie, istotnie różne techniki spawania. Spawając materiały trudnospawalne, a szczególnie wykonując ich złącza o znacznej sztywności należy regulować ściegową i sumaryczną energię liniową poprzez stosowanie właściwej, określanej doświadczalnie technologii i techniki spawania.

W przeciwnym przypadku naprężenia pospawalnicze mogą okazać się niedostatecznie redukowalne, a zmiany strukturalne złącza nieodwracalne, mimo zastosowania wyżarzania odprężającego - w omawianym przypadku w temperaturze $600{ }^{\circ} \mathrm{C}$. Niezachowanie właściwych reżimów spawania owocować może spadkiem udarności złącza.

\section{Literatura}

[1] A. Ziewiec, K. Pańcikiewicz, E. Tasak: Pękanie spoin w stali 7CrMoVTiB10-10 (T24) w czasie spawania, uruchamiania i eksploatacji blo-

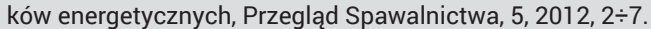

[2] J. Michalczyk, Wojsyk K.: Bezpieczne i ekonomiczne konstruowanie ekranów wymienników ciepła ze stali i innych stopów o ograniczonej

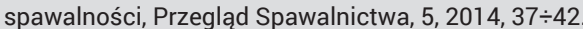

[3] K. Pańcikiewicz, E. Tasak: Charakter pękania połączeń spawanych

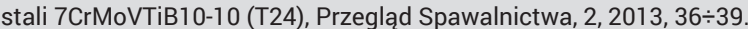

[4] K. Pańcikiewicz, A. Zielińska-Lipiec, E. Tasak: Mikrostruktura i właściwości mechaniczne złączy stali T24 spawanych metodami konwencjonalnymi i wysokoenergetycznymi, Przegląd Spawalnictwa, 4, $2014,5 \div 10$.
[5] W. Gawrysiuk: Spawanie hybrydowe (laser + MAG) paneli ścian szczelnych kottów energetycznych ze stali 7CrMoVTiB10-10, Prze-

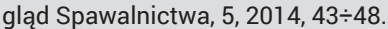

[6] G. M. Grigorenko, W. A. Kostin: Spawalność stali i kryteria jej oceny, Przegląd Spawalnictwa, 7, 2013, 11 $\div 17$.

[7] E. Tasak, A. Ziewiec, Spawalność materiałów konstrukcyjnych. Tom 1-Spawalność stali, Wydawnictwo JAK, Kraków, 2009.

[8] Sobala M.: Spawalność wybranych stali i staliw wysokostopowych. Próba spawania staliwa GX5CrNi13-4, Częstochowa, 2013

[9] J. Pilarczyk, J. Pilarczyk: Spawanie i napa-wanie elektryczne metali, Wydanie II, Wyd. „Śląsk”, Katowice, 1996, 112 $\div 116$ 